\title{
ELF AWARENESS AND PEDAGOGICAL IMPLICATIONS IN ELT CLASSROOMS. INTRODUCTION TO SPECIAL ISSUE
}

TOMADA DE CONSCIÊNCIA SOBRE O INGLÊS COMO LÍNGUA FRANCA E AS IMPLICAÇÕES PARA O ENSINO DE LÍNGUA INGLESA (ELI). INTRODUÇÃO À EDIÇÃO ESPECIAL

Enrico Grazzi

Roma Trè University, Italy

Lucilla Lopriore Roma Trè University, Italy

Sávio Siqueira Bahia Federal University, Brazil

The theme of this Special Issue ${ }^{1}$ of Estudos Linguísticos e Literários follows from a colloquium entitled New Trajectories in Teacher Education: ELF awareness and pedagogical implications in ELT classrooms, which was organised by Enrico Grazzi and Lucilla Lopriore at the 11th International Conference on English as a Lingua Franca (ELF11), King's College, London, July 2018. ELF scholar and colleague Martin Dewey from King's College was the discussant.

Our aim with this endeavor is to provide the reader with a detailed insight into the interplay between academic research and ELF-aware teacher education from some of the scholars in the field who have been involved in their countries as teacher educators in ELT courses under an ELF-perspective, and have investigated teachers' beliefs and attitudes within those contexts. The

1 The names of the editors are listed in alphabetical order. 
Colloquium presenters at the conference - Andrew Blair, Enrico Grazzi, Lili Cavalheiro, Lucilla Lopriore, Luis Guerra, Inmaculada Pineda Hernandez, Nikos Sifakis, and Sávio Siqueira - all have contributed to this special issue. Telma Gimenez, Luciana Cabrini and Michele El Kadri, presenters at the same conference with a different paper, were invited to contribute to this issue since the theme of their paper was very close to the theme of the colloquium.

The world of English Language Teaching (ELT) has so far proven almost impermeable to the reconceptualization of English as a lingua franca (ELF) in the age of globalization. Native speakerism is still deeply entrenched in school education, therefore, one of today's new aims in teacher education is to rely upon the findings of ELF research in order to promote projects and initiatives that may enhance an ELF-aware approach in the language classroom. It is in this spirit that we hope this special issue will contribute to an improved understanding of the complexity of the tasks that lie ahead. All contributors of this special issue primarily focus on raising understanding of ELF in order to change the traditional paradigm of language education with a look at the future of ELT. A brief synopsis of each contribution, thematically organised, follows.

We start with Andrew Blair whose aim in his paper entitled Developing 'ELF Competence' in Language Learners and Teachers, is to discuss the 'contested' notion of competence and the challenges this term is facing within the new English language teaching and learning scenarios triggered by the diffusion of ELF and by teachers' resistance to revisit their attitudes and beliefs. Blair describes the undergoing changes occurring in language education and highlights the challenges faced by teachers revisiting their approach within an ELF-aware perspective.

In Developing Intercultural Communication and Intercultural Awareness in the EFL Classroom, Lili Cavalheiro revisits and reframes the notion of intercultural communication within the scenario of current global migration movements that have turned classrooms into multilingual contexts where English functions as the common medium of communication 'par excellence'. The actions undertaken in the MA pre-service teacher education courses at the University of Lisbon where Cavalheiro works, specifically the more interculturally ELF-aware approach adopted, are described and discussed.

In ELF-Awareness and Intercultural Communicative Competence in ELT Policies in Portugal, Luis Guerra discusses a study where he examined official documents published by the Council of Europe and the Portuguese Ministry of 
Education to verify if and how the concepts of Intercultural Communicative Competence (ICC) and English as a Lingua Franca (ELF) are theoretically and practically formulated. Findings show a rather traditional approach to language pedagogy that misrepresents the role of ELF and ICC.

Enrico Grazzi and Lucilla Lopriore in ELF Awareness for Teacher Education in Italy: Attitudes and Actions, present and discuss some of the findings of a national research study on teachers' attitudes and beliefs towards the changing scenarios opened by Global Englishes and ELF in ELT. The questions they worked on were meant to trigger teachers' personal stance and positioning as for their attitudes and beliefs regarding the English language and ELT. Teachers' current perceptions reveal the need to focus on the pedagogical implications of an ELF-aware approach in the language classroom.

In her article, Teaching ELF-Aware Pedagogical Strategies to EMI Professors of Architecture, Inmaculada Pineda Hernandez describes the implementation of a Spanish training programme for EMI professors of Architecture at the University of Málaga, Spain. The aims of this project are to improve content lecturers' linguistic skills in ELF and to develop methodological strategies to improve learning in an academic setting.

In Two Obstacles to Enabling Change in ELF-Aware Teacher Education and How to Overcome Them, Nicos Sifakis discusses the implications of applying the ELFaware perspective in teacher education. In particular, he takes into consideration two major hindrances, namely a) teachers' negative attitude towards ELF; and b) uncertainty about the whole process of developing ELF-informed pedagogy. The author concludes by showing how possible it is to cope with these major obstacles.

Sávio Siqueira, in ELT Materials for Basic Education in Brazil: Is There Room for an ELF-Aware Practice?, presents and discusses results of a study conducted in a pre-service teacher education program at Bahia Federal University (UFBA), Salvador, Brazil, his place of work. According to the author, the purpose of the study was to try and adapt EFL-based textbook activities to an ELF-oriented perspective. Findings indicate that it is possible to incorporate ELF-aware pedagogy into the English syllabus, to respond to the communicative needs of the local learning context.

The final contribution, Teachers Learning about English as a Lingua Franca on Facebook: Insights from a Community of Practice, by Telma Gimenez, Michele El Kadri and Luciana Calvo, is aimed at sharing the relevance of changes occurring 
in teachers' attitudes and beliefs when teachers are called upon to participate and engage in a community of practice through Facebook. The authors describe how the discussions on the meanings of ELF enhanced a reflective process towards possible changes and how this process was contextualized in the classrooms of a Brazilian virtual community of teachers (BrELT-Brazil's English Language Teachers).

Last but not least, we would like to express our deep gratitude to the main Editor of UFBA's Estudos Linguísticos e Literários, Prof. José Amarante Sobrinho, for unconditionally accepting and embracing the proposal for this special edition, and also all the colleagues in Brazil and abroad who took a bit of their precious and busy time to help us with the blind reviews of the manuscripts.

Along with the possibility of granting Estudos Linguísticos e Literários a broader international audience, this entreprise has also served as a prime opportunity for ELF scholars from Brazil and different parts of Europe to cooperate once again in a project which basically envisions an ongoing and lasting exchange of ideas and reflections. As we know, despite the different contexts in which we work and militate, we do have numerous aspects in common and a lot to learn from one another. We hope readers enjoy exploring the texts as much as we enjoyed putting all of them together.

\author{
Enrico Grazzi, \\ Lucilla Lopriore \\ and Sávio Siqueira (Editors)
}

